\title{
Green Needlegrass and Blue Grama Seedling Growth in Controlled Environments
}

TIMOTHY E. FULBRIGHT, A.M. WILSON, AND EDWARD F. REDENTE

\begin{abstract}
Green needlegrass [Stipa viridula Trin.] and blue grama [Bouteloua gracilis (H.B.K.) Lag.] possess the $C_{3}$ and $C_{4}$ photosynthetic pathways, respectively. Objectives of this study were to compare growth analysis traits of green needlegrass and blue grama and to determine the effects of 2 temperature regimes on seedling growth characteristics of both species. Seedlings of 2 accessions each of green needlegrass and blue grama were grown in growth chambers under $20^{\circ} \mathrm{C}$ day-15 ${ }^{\circ} \mathrm{C}$ night $\left(20-15^{\circ} \mathrm{C}\right)$ and $25^{\circ} \mathrm{C}$ day-20 $\mathrm{C}$ night (25-20 $\mathrm{C}$ ) temperature regimes (with a 15-hr photoperiod). Beginning 2 weeks after planting, seedlings were harvested twice a week for 3 weeks. Growth analysis traits were calculated with data obtained from each harvest using exponential regression equations. Net assimilation rates of blue grama were higher than those of green needlegrass at both temperatures. Seedling growth of blue grama was more rapid at $25-20^{\circ}$ than at $20-15^{\circ} \mathrm{C}$, while seedling growth of green needlegrass did not differ between temperatures. Blue grama seedlings exhibited higher relative growth rates than green needlegrass seedlings at $25-20^{\circ} \mathrm{C}$ but not at $20-15^{\circ} \mathrm{C}$. Green needlegrass accessions differed for relative growth rates at 25$20^{\circ} \mathrm{C}$, which indicated the possibility of selecting for rapid seedling growth.
\end{abstract}

Authors are former graduate research assistant, Department of Range Science. Colorado State University, Fort Collins; now assistant professor, College of Agriculture, Texas A\&I University, Kingsville, Texas 78363; plant physiologist, USDA-ARS, Crop Research Laboratory, Fort Cullins (deceased); and associate professor, Department of Range Science, Colorado State University, Fort Collins 80523.

Research was supported in part by the U.S. Department of Energy under Contract No. DE-AS02-76EV04018.

Manuscript accepted October 29, 1984.
Amount of leaf area present and net assimilation rate (NAR) govern the rate of seedling growth. Gruwth analysis provides a means of determining the relative importance of leaf area and net assimilation rate in seedling growth rates (Patterson et al. 1978).

Potter and Jones (1977) found plant growth to be more closely correlated with leaf area partitioning coefficient (LAP) than with NAR. LAP indicates that extent of partitioning of daily assimilation into new leaf area. Relative leaf a rea expansion rate $\left(K_{a}\right)$ is the product of NAR and LAP. Various investigators have reported high correlations between relative leaf area expansion rates and growth (Potter and Jones 1977, Patterson et al. 1978, Townsend and Wilson 1981).

Green needlegrass (Stipa viridula Trin.) possesses the $C_{3}$ photosynthetic pathway (Waller and Lewis 1979). Blue grama [Bouteloua gracilis (H.B.K.) Lag.], a common associate of green needlegrass throughout much of its range, possesses the $\mathrm{C}_{4}$ pathway. Growth rates of blue grama and green needlegrass would be expected to differ because of the physiological dissimilarities between the 2 species. Objectives of this study were to use growth analysis traits to (1) explain differences in seedling growth rates between blue grama and green needlegrass and (2) determine the influence of temperature on seedling growth of each species. Growth analysis can be used in screening plant materials for traits that enhance seedling vigor (Townsend and Wilson 1978, 1981). A third objective of the study was to determine the influence of accession on seedling growth of each species. 


\section{Materials and Methods}

Seeds of Lodorm and accession SD-93 green needlegrass were obtained from the USDA Soil Conservation Service Plant Materials Center at Bismarck, N. Dak. Lodorm is a variety of green needlegrass with reduced seed dormancy (Larson and Carter 1970). Blue grama accessions were PM-K-1482 and PM-K-1483. Accession PM-K-1482 is a synthetic blend of 6 blue grama accessions that originated in Nebraska and northern Kansas. Accession PM-K-1483 is a synthetic blend of 12 blue grama accessions from southern Kansas and northwestern Texas.

Seeds were planted in plastic pots $(15 \mathrm{~cm}$ diameter by $15 \mathrm{~cm}$ deep) filled with autoclaved sandy loam soil. Thirty seeds were placed in each pot and covered with $2 \mathrm{~mm}$ of soil. Soil in each pot was watered to approximately field capacity. Seeds were then covered with a $2-\mathrm{cm}$ layer of dry soil.

The experiment was conducted in 2 sequential phases: (1) a 14-day emergence and initial seedling growth phase and (2) a 21-day temperature treatment phase. In the first phase pots were placed in a growth chamber at a $20-15^{\circ} \mathrm{C}$ temperature regime with a 15-hr photoperiod. Photosynthetic photon flux density (PPFD) was $400 \mu \mathrm{E} \mathrm{M}^{-2} \mathrm{~s}^{-1}$. Pots were subirrigated to retain the dry surface layer of soil. Soil below the dry layer was maintained at about field capacity.

In the second phase of the experiment, pots were removed from the first growth chamber and seedlings were thinned to the 5 largest in each pot. A layer of gravel was placed on the soil surface of each pot to reduce evaporation. Pots were then placed in 1 of 2 growth chambers adjusted for temperature regimes of $20-15^{\circ} \mathrm{C}$ and 25 $20^{\circ} \mathrm{C}$. PPFD was $450 \mu \mathrm{E} \mathrm{M}^{-2} \mathrm{~s}^{-1}$ during the $15-\mathrm{hr}$ photoperiod. Pots were surface irrigated when necessary during the second phase of the experiment to maintain the soil at field capacity.

Seedlings were harvested immediately before the temperature treatment phase and then twice a week for 3 weeks. A total of 7 harvests were made. All data were based on averages of the 5 seedlings in each pot. Each harvest consisted of first counting tillers then excising excerted leaf blades. Leaf blade area was measured with an automatic leaf area meter having a sensitivity of $0.1 \mathrm{~mm}$. Soil was removed from each pot, placed on a screen, and carefully washed from seedling roots with a fine spray of water. Seedlings were then taken to the laboratory and placed on moist blotter paper. Seminal and adventitious roots were excised with a razor blade and counted. Leaf blades, roots, and other seedling parts were oven-dried at $60^{\circ} \mathrm{C}$ for 24 hours and then weighed.

Data obtained from the 7 harvests were used to calculate the following seedling growth traits: net assimilation rate (NAR), leaf area partitioning coefficient (LAP), relative leaf area expansion rate $\left(K_{\mathbf{a}}\right)$, relative growth rate $\left(\mathrm{K}_{\mathbf{w}}\right)$, relative rate of shoot development $\left(K_{\mathrm{s}}\right)$, and relative rate of root development per shoot $\left(\mathrm{K}_{\mathrm{r}}\right)$. Definitions and units of measurement for each growth trait are given in Table 1 .

Seedling growth traits were calculated using exponential regression equations described by Potter and Jones (1977) of the form:

$$
w=w_{o} \mathbf{k}^{\mathbf{K}} \mathbf{w}^{2}
$$

where $\mathrm{W}$ is total seedling weight $(\mathrm{mg})$ at any given time, $\mathrm{W}_{\mathrm{o}}$ is initial seedling weight $(\mathrm{mg}), K_{w}$ is relative growth rate, and $t$ is time (days). The value of $t$ in calculations of NAR and LAP was 14 since LAP and NAR were estimated 14 days after the start of the 2 temperature treatments. Values for each seedling growth trait were calculated for each temperature regime, accession, and replication to allow statistical comparisons.

A randomized complete-block design with a factorial arrangement of treatments was used in the experiment. Factors were temperature regimes, accessions, and harvest dates. Five replications were conducted sequentially over time and data were analyzed by analysis of variance and polynomial regression. Simple correlation coefficients $(\tau)$ and linear regression coefficients (b)
Table 1. Definitions and units of measurement of traits used to describe seedling growth of 2 accessions each of green needlegrass and blue grama. 1

\begin{tabular}{|c|c|c|}
\hline Trait & Definition ${ }^{2}$ & Units \\
\hline \multirow[t]{2}{*}{ Net assimilation rate (NAR) ${ }^{3}$} & $\mathrm{dW} / \mathrm{dt}$ & $\mathrm{mg} \mathrm{day}^{-1}$ \\
\hline & A & $\mathrm{cm}^{2}$ \\
\hline \multirow{2}{*}{$\begin{array}{l}\text { Leaf area partitioning coefficient } \\
\text { (LAP) }\end{array}$} & $\mathrm{dA} / \mathrm{dt}$ & $\mathrm{cm}^{2}$ day $^{-1}$ \\
\hline & $\mathrm{dW} / \mathrm{dt}$ & $\overline{\text { mg day }^{-1}}$ \\
\hline \multirow[t]{2}{*}{ Relative leaf area expansion rate $\left(K_{\mathbf{a}}\right)$} & $\mathrm{dA} / \mathrm{dt}$ & $\mathrm{cm}^{2}$ day $^{-1}$ \\
\hline & $\mathbf{A}$ & $\mathrm{cm}^{2}$ \\
\hline \multirow[t]{2}{*}{ Relative growth rate $\left(K_{w}\right)$} & $\mathrm{dW} / \mathrm{dt}$ & $\mathrm{mg}_{\mathrm{day}}{ }^{-1}$ \\
\hline & w & $\mathrm{mg}$ \\
\hline \multirow{2}{*}{$\begin{array}{l}\text { Relative rate of shoot development } \\
\left(\mathbf{K}_{\mathbf{\varepsilon}}\right)\end{array}$} & $\mathrm{dS} / \mathrm{dt}$ & No. shoots day ${ }^{-1}$ \\
\hline & $\mathbf{S}$ & No. shoots \\
\hline \multirow{2}{*}{$\begin{array}{l}\text { Relative rate of root development } \\
\left(\mathbf{K}_{r}\right)\end{array}$} & $\mathrm{dR} / \mathrm{dt}$ & No. roots day ${ }^{-1}$ \\
\hline & $\mathbf{S}$ & $\overline{\text { No. shoots }}$ \\
\hline
\end{tabular}

'Adapted from Townsend and Wilson (1981).

${ }^{2}$ The following abbreviations we "

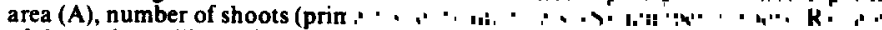
of change in seedling weight (dW.. d: , .

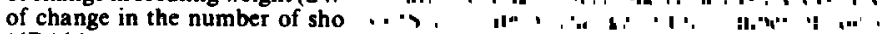
(dR/dt).

${ }^{3}$ LAP and NAR were estimated on the fifth harvest date (14 days after the beginning of temperature treatments).

werc calculated to examine relationships between seedling growth traits. All differences were significant at the 0.05 level of probability unless otherwise stated.

\section{Results}

\section{Leaf Blade Area and Total Seedling Weight}

Green needlegrass seedlings developed greater leaf blade area than blue grama seedlings under the $20-15^{\circ} \mathrm{C}$ temperature regime (Table 2). Leaf blade area of green needlegrass seedlings did not differ between temperature treatments while that of blue grama was greater under the warmer temperature regime than under the cooler regime. Lodorm green needlegrass seedlings had greater leaf blade area than SD-93 green needlegrass seedlings under both temperature regimes. Seedlings of accession PM-K-1483 blue grama developed greater leaf blade area than PM-K-1482 blue grama seedlings under the $25-20^{\circ} \mathrm{C}$ temperature regime but not under the $20-15^{\circ} \mathrm{C}$ regime.

Leaf blade area of green needlegrass seedlings was more than double that of blue grama seedlings on the first harvest date (Table 2). Leaf blade area on the first harvest date was highly correlated $(r=0.81, p<0.01)$ with caryopsis weight. Weight of Lodorm and SD-93 green needlegrass caryopses averaged 1.2 and $1.5 \mathrm{mg}$, respectively, compared to $0.4 \mathrm{mg}$ for caryopses of the blue grama accessions. Differences in leaf blade area between species were probably associated with differences in caryopsis weight. Townsend and Wilson (1981) found that seed weight of cicer milkvetch [Astragalus cicer $L$.] was positively associated with initial leaf area and initial seedling weight, but net assimilation rate, leaf area partitioning coefficient, relative leaf area expansion rate, and relative growth rate were entirely independent of seed weight.

Total weight of green needlegrass seedlings was $28 \%$ higher than that of blue grama seedlings on the final harvest date under the $20-15^{\circ} \mathrm{C}$ temperature regime, but total weight of green needlegrass seedlings was $32 \%$ lower than that of blue grama seedlings at $25-20^{\circ} \mathrm{C}$ on the final harvest date (Table 2). Total weight of green needlegrass seedlings did not differ between temperature treatments, while blue grama seedlings developed greater total weight at $25-20^{\circ} \mathrm{C}$ than at $20-15^{\circ} \mathrm{C}$. Lodorm green needlegrass seedlings accumulated more dry matter than SD-93 seedlings. Seedlings of accession PM-K-1483 blue grama developed greater total seedling weight than PM-K-1482 blue grama seedlings under the $25-20^{\circ} \mathrm{C}$ 
Table 2. Leaf blade area $\left(\mathrm{cm}^{2}\right)$ and total seedling weight $(\mathrm{mg})$ of 2 accessions each of green needlegrass and blue grama grown under 2 different temperature regimes.

\begin{tabular}{|c|c|c|c|c|c|}
\hline \multirow[b]{2}{*}{ Species } & \multirow{2}{*}{$\begin{array}{l}\text { Accession and days } \\
\text { after planting }\end{array}$} & \multicolumn{2}{|c|}{$\begin{array}{c}\text { Leaf blade area } 1 \\
\left(\mathrm{~cm}^{2}\right)\end{array}$} & \multicolumn{2}{|c|}{$\begin{array}{c}\text { Total seedling weight }{ }^{\prime} \\
(\mathrm{mg})\end{array}$} \\
\hline & & $20-15^{\circ} \mathrm{C}$ & $25-20^{\circ} \mathrm{C}$ & $20-15^{\circ} \mathrm{C}$ & $25-20^{\circ} \mathrm{C}$ \\
\hline Green needlegrass & $\begin{array}{c}\text { Lodorm } \\
14 \\
18 \\
21 \\
25 \\
28 \\
32 \\
35 \\
\bar{x} \pm 95 \% \\
\text { Confidence interval } \\
\text { SD-93 } \\
14 \\
18 \\
21 \\
25 \\
28 \\
32 \\
35 \\
\bar{x} \pm 95 \% \\
\text { Confidence interval }\end{array}$ & $\begin{array}{r}1.2 \\
2.4 \\
4.6 \\
8.7 \\
14.9 \\
19.6 \\
29.9 \\
11.6 \pm 1.2\end{array}$ & $\begin{array}{r}1.7 \\
2.9 \\
5.3 \\
9.1 \\
15.0 \\
20.9 \\
31.6 \\
12.4 \pm 1.2\end{array}$ & $\begin{array}{l}15 \\
28 \\
51 \\
97 \\
180 \\
257 \\
409 \\
148 \pm 24\end{array}$ & $\begin{array}{r}19 \\
31 \\
58 \\
109 \\
187 \\
284 \\
462 \\
164 \pm 24\end{array}$ \\
\hline Blue Grama & $\begin{array}{c}\text { PM-K-1482 } \\
14 \\
18 \\
21 \\
25 \\
28 \\
32 \\
35 \\
\bar{x} \pm 95 \% \\
\text { Confidence Interval } \\
\text { PM-K-1483 } \\
14 \\
18 \\
21 \\
25 \\
28 \\
32 \\
35 \\
\bar{x} \pm 95 \% \\
\text { Confidence Interval }\end{array}$ & $\begin{array}{c}0.6 \\
0.9 \\
1.6 \\
3.7 \\
6.3 \\
9.4 \\
16.9 \\
5.6 \pm 1.2\end{array}$ & $\begin{array}{r}0.5 \\
1.4 \\
2.8 \\
7.3 \\
11.8 \\
20.8 \\
31.5 \\
10.9 \pm 1.2\end{array}$ & $\begin{array}{l}15 \\
24 \\
39 \\
80 \\
128 \\
200 \\
349 \\
119 \pm 24\end{array}$ & $\begin{array}{r}13 \\
29 \\
54 \\
127 \\
216 \\
378 \\
691 \\
215 \pm 24\end{array}$ \\
\hline
\end{tabular}

'Analysis of variance indicated significant $(\mathrm{p}<0.05)$ main effects for temperatures, accessions, and planting dates. In addition, all 2-way and 3-way interactions were significant $(p<0.05)$. The pooled confidence interval is appropriate for differences between treatment combinations but not for identifying significantly different main effects and interaction means.

temperature regime but not under the $20-15^{\circ} \mathrm{C}$ regime.

\section{Net Assimilation Rate (NAR) and Leaf Area \\ Partitioning Coefficient (LAP)}

Blue grama seedlings exhibited higher values for NAR than did green needlegrass seedlings (Table 3). NAR values were higher at $25-20^{\circ} \mathrm{C}$ than at $20-15^{\circ} \mathrm{C}$. NAR did not differ bet ween green needlegrass accessions or between blue grama accessions.

Green needlegrass seedlings had higher values for LAP than blue grama seedlings at both temperatures (Fig. 1). There was an interaction of accession with temperature for LAP. LAP of green needlegrass seedlings tended to be lower at $25-20^{\circ} \mathrm{C}$, while LAP of blue grama seedlings tended to be higher at $25-20^{\circ} \mathrm{C}$ than at $20-15^{\circ} \mathrm{C}$. No difference in I.AP existed between green needlegrass accessions or between blue grama accessions.

\section{Relative Leaf Area Expansion Rate $\left(K_{a}\right)$ and}

\section{Relative Growth Rate ( $\left.\mathbf{K}_{\mathbf{w}}\right)$}

Blue grama seedlings had higher values for $K_{a}$ than green needlegrass seedlings at $25-20^{\circ} \mathrm{C}$ but not at $20-15^{\circ} \mathrm{C}$ (Fig. 2). $\mathrm{K}_{\mathrm{a}}$ of green needlegrass seedlings did not differ between temperatures. Blue grama seedlings had $17 \%$ higher values for $\mathbf{K}_{\mathbf{a}}$ under the the $25-20^{\circ} \mathrm{C}$ temperature regime than under the $20-15^{\circ} \mathrm{C}$ regime. No diffcrencc existed between green needlegrass accessions or between blue grama accessions for $\mathbf{K}_{\mathbf{a}}$.

$\mathrm{K}_{\mathbf{w}}$ of blue grama seedlings exceeded that of green needlegrass seedlings at $25-20^{\circ} \mathrm{C}$ (Fig. 3). Blue grama and green needlegrass had similar values for $\mathrm{K}_{\mathrm{w}}$ at $20-15^{\circ} \mathrm{C}$. $\mathrm{K}_{\mathrm{w}}$ of green needlegrass did not differ between temperature treatments. Blue grama seedlings had higher values for $\mathrm{K}_{\mathrm{w}}$ under the $25-20^{\circ} \mathrm{C}$ temperature regime than under the $20-15^{\circ} \mathrm{C}$ regime. Lodorm green needlegrass seedlings exhibited higher values for $\mathrm{K}_{\mathbf{w}}$ than SD-93 green needlegrass seedlings at $25-20^{\circ} \mathrm{C}$ but not at $20-15^{\circ} \mathrm{C}$. There was no difference in $\mathrm{K}_{\mathbf{w}}$ between blue grama accessions.

Differences in growth rates between green needlegrass and blue grama seedlings can be explained by the relationship between $\mathrm{K}_{\mathbf{w}}$ and $K_{a} \cdot K_{w}$ was more highly correlated with $K_{a}$ than with NAR for all accessions except SD-93 green needlegrass (Table 4). There was no significant correlation between $K_{w}$ and LAP. Thus, blue grama 
Table 3. Net assimilation rate (NAR), relative rate of shoot development $\left(K_{s}\right)$, and relative rate of root development per shoot $\left(K_{r}\right)$ of 2 accessions each of green needlegrass and blue grama grown under 2 temperature regimes.

\begin{tabular}{|c|c|c|c|c|}
\hline \multirow[b]{2}{*}{ Species } & \multirow{2}{*}{$\begin{array}{l}\text { Temperature and } \\
\text { accession }\end{array}$} & \multicolumn{3}{|c|}{ Seedling growth trait ${ }^{1,2,3,4}$} \\
\hline & & NAR & $\mathrm{K}_{\mathbf{s}}$ & $\mathbf{K}_{\mathbf{r}}$ \\
\hline \multirow{3}{*}{ Green needlegrass } & $20-15^{\circ} \mathrm{C}$ & & & \\
\hline & Lodorm & 2.04 & 0.06 & 0.27 \\
\hline & SD-93 & 1.98 & 0.06 & 0.33 \\
\hline \multirow[t]{3}{*}{ Blue grama } & PM-K-1482 & 3.30 & 0.08 & 0.11 \\
\hline & PM-K- 1483 & 3.28 & 0.09 & 0.10 \\
\hline & $25-20^{\circ} \mathrm{C}$ & & & \\
\hline \multirow[t]{2}{*}{ Green needlegrass } & Lodorm & 2.19 & 0.07 & 0.31 \\
\hline & SD-93 & 1.98 & 0.07 & 0.34 \\
\hline \multirow[t]{3}{*}{ Blue grama } & PM-K-1482 & 3.76 & 0.09 & 0.13 \\
\hline & PM-K-1483 & 3.56 & 0.10 & 0.13 \\
\hline & $\begin{array}{l}95 \% \text { Confidence } \\
\text { Interval }\end{array}$ & $x \pm 0.34$ & $\bar{x} \pm 0.01$ & $\bar{x}+0.03$ \\
\hline
\end{tabular}

'Values of $R$ ' for equations used 10 calculate these iraits for each replication ranged from 0.83 to 0.99 .

Interactions of temperature treatments with accessions were not significant $(p>0.05)$ for NAR. $K_{s}$ and $K_{r}$. Main effects of temperature and accession were significant $(p<0.05)$ for $N A R, K_{s}$, and $K_{r}$.

${ }^{3} \mathrm{NAR}$ in mg day ${ }^{1} \mathrm{~cm}^{2}: \mathrm{K}_{\mathrm{s}}$ in no. of shoots day ${ }^{1}$ no. of shoots; $\mathrm{K}_{z}$ in no. of roots day ${ }^{-1}$ no. of shoots.

${ }^{4}$ The pooled confidence interval is appropriate for differences between treatment combinations but not for identifying significantly different main effects and interaction means.

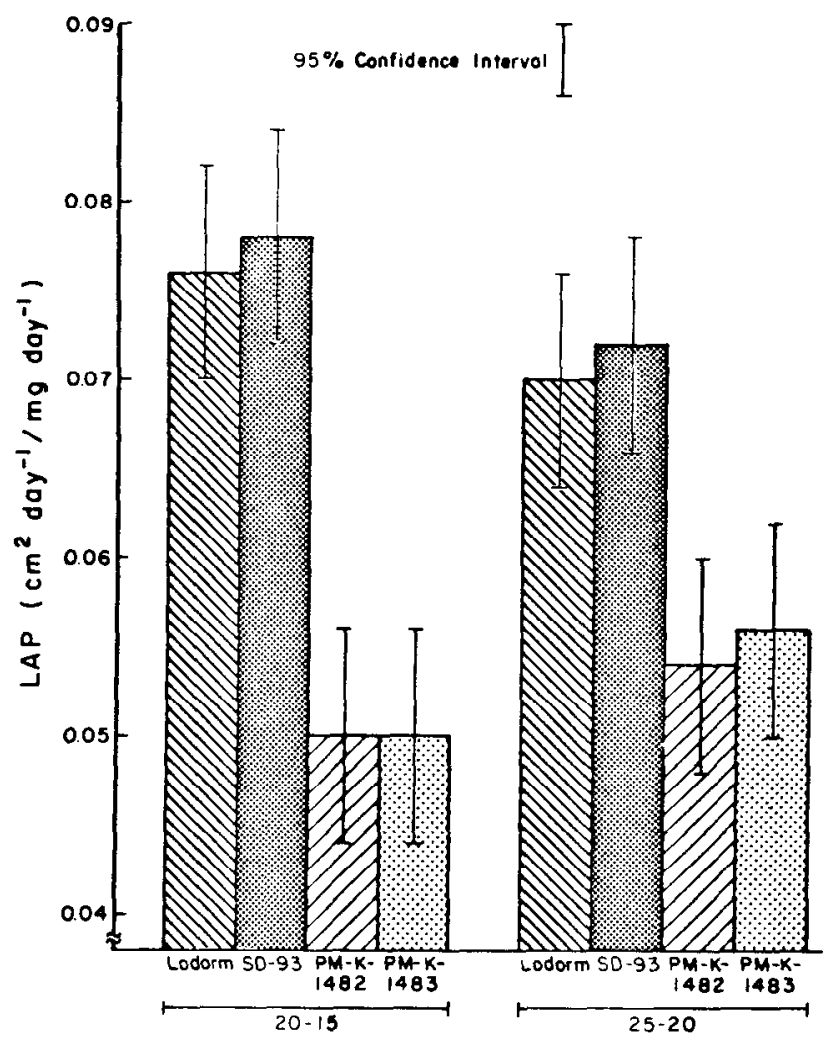

TEMPERATURE $\left({ }^{\circ} \mathrm{C}\right)$

Fig. 1. Temperature effects on leaf area partitioning coefficient ( $L A P)$ of 2 accessions each of green needlegrass and blue grama. The interaction of accession and temperature was significant $(\mathrm{p}<0.05)$. The muin effect of temperature was not significant ( $>0.05)$, and the main effect of accession was significant $(\mathrm{p}<0.05)$. The pooled confidence intervals are appropriate for differences between treatment combinations but not for identifying significantly different main effects and interaction means.

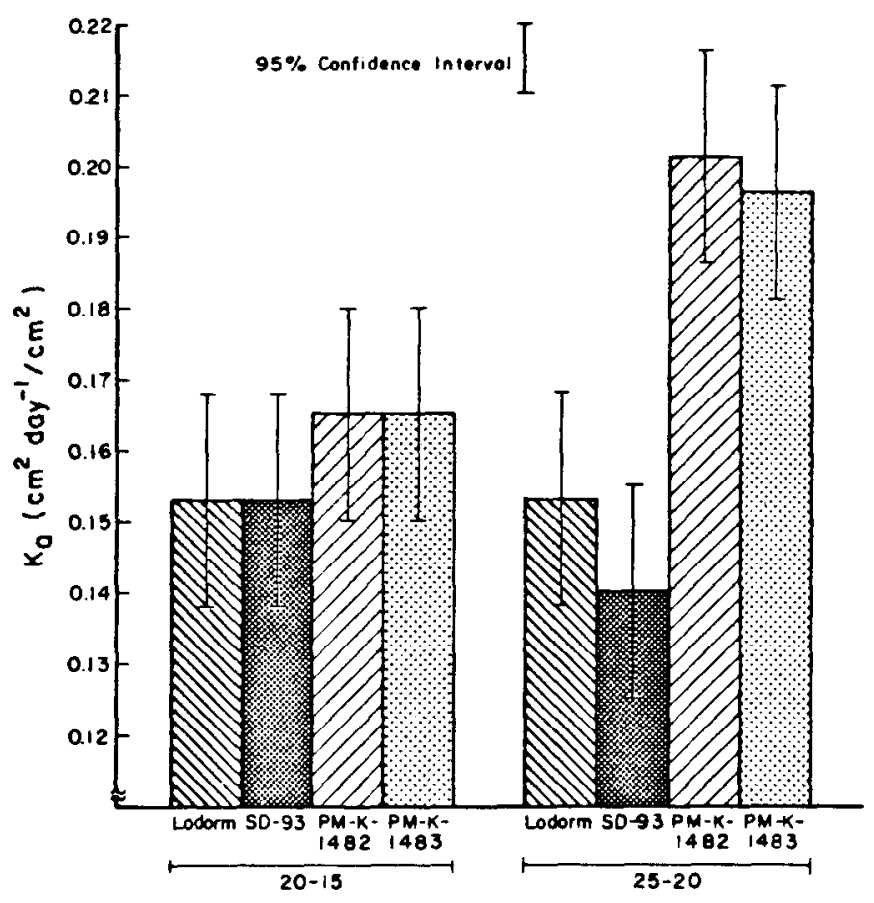

TEMPERATURE $\left({ }^{\circ} \mathrm{C}\right)$

Fig. 2. Temperature effects on relative leaf area expansion rate $\left(K_{\mathrm{a}}\right)$ of 2 accessions each of green needlegrass and blue grama. The interaction of accession and temperature was significant $(\mathrm{p}<0.05)$. Main effects of temperature and accession were also significant $(\mathrm{p}<0.05)$. The pooled confidence interval is appropriate for differences between treatment combinations but not for identifying significantly different main effects and interaction means.

seedlings had higher $\mathrm{K}_{\mathrm{w}}$ values than green needlegrass at $25-20^{\circ} \mathrm{C}$ because $K_{a}$ values of blue grama were higher than those of green needlegrass seedlings (Table 3 ). $\mathrm{K}_{\mathrm{w}}$ values of the 2 species were similar under the $20-15^{\circ} \mathrm{C}$ temperature regimes because $\mathrm{K}_{\mathrm{a}}$ values did not differ.

Differences between species in the effect of temperature on growth rates can also be explained by the relationship between $\mathrm{K}_{\mathrm{w}}$ and $K_{\mathbf{a}} \cdot \mathbf{K}_{\mathbf{w}}$ of green needlegrass seedlings did not differ between temperature treatments because $\mathbf{K}_{\mathbf{a}}$ did not differ between temperatures (Table 3 ). Blue grama had a higher $K_{w}$ at $25-20^{\circ} \mathrm{C}$ than at $20-15^{\circ} \mathrm{C}$ because $\mathrm{K}_{\mathrm{a}}$ was highest at $25-20^{\circ} \mathrm{C}$.

The higher $\mathrm{K}_{\mathrm{w}}$ of Lodorm green needlegrass seedlings in comparison to SD-93 green needlegrass seedlings may have resulted in part from the greater leaf blade area of Lodorm. Also, $K_{a}$ and NAR of Lodorm tended to be higher than that of SD-93, although neither trait differed significantly between the 2 accessions. Blue grama accessions did not exhibit differences in $K_{w}$ bccause they did not differ in $K_{a}$, LAP, or NAR.

\section{Relative Rate of Shoot Development $\left(K_{\mathrm{s}}\right)$ and Relative Rate of Root Development Per Shoot $\left(K_{r}\right)$}

Blue grama seedlings exhibited a higher $\mathbf{K}_{\mathrm{s}}$ than green needlegrass seedlings (Table 3 ). Blue grama seedlings had an average of 1.2 tillers on the first harvest date, when seedlings were 2 weeks old. Green needlegrass seedlings did not develop tillers until the third harvest date, when seedlings were 3 weeks old. Blue grama seedlings had an average of 15.6 tillers on the final harvest date at $25-20^{\circ} \mathrm{C}$. compared to 2.6 for grcen needlegrass. $\mathrm{K}_{\mathrm{s}}$ was more rapid at $25-20^{\circ} \mathrm{C}$ than at $20-15^{\circ} \mathrm{C}$ and did not differ between accessions for either species.

Green needlegrass seedlings had higher values for $\mathbf{K}_{\mathbf{r}}$ than did blue gra ma seedlings under both temperature treatments (Table 3 ). The higher values of $\mathbf{K}_{\mathrm{r}}$ for green needlegrass possibly resulted from the greater size of green needlegrass shoots and decper 


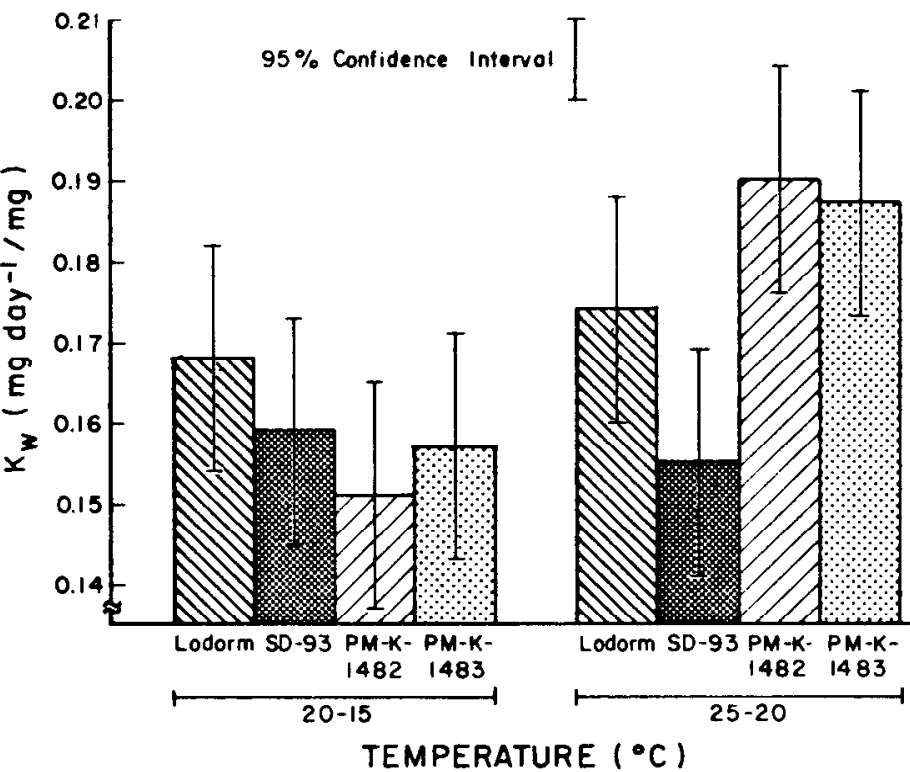

Fig. 3. Temperature effects on relative growth rate $\left(K_{\mathrm{w}}\right)$ of 2 accessions each of green needlegrass and blue grama. The interaction of accession and temperature was significant $(\mathrm{p}<0.05)$. Main effects of temperature and accession were also significant $(\mathrm{p}<0.05)$. The pooled confidence intervals are appropriate for differences between treatment combinations but not for identifying significantly different main effects and interaction means.

placement of the coleoptilar node, from which the adventitious roots develop, in the soil. Although $\mathbf{K}_{\mathbf{r}}$ of green needlegrass was higher than that of blue grama, blue grama seedlings developed a greater total number of adventitious roots than green needlegrass seedlings because blue grama seedlings developed a greater total number of shoots than green needlegrass seedlings. Blue grama seedlings had an average of 22.4 adventitious roots per seedling on the final harvest date at $25-20^{\circ} \mathrm{C}$, compared to 12.9 for green needlegrass seedlings. $K_{r}$ was more rapid at $25-20^{\circ} \mathrm{C}$ than at 20 $15^{\circ} \mathrm{C}$. SD-93 green needlegrass seedlings had higher values for $\mathrm{K}_{\mathrm{r}}$ than did Lodorm seedlings. Blue grama accessions did not differ in Kr.

\section{Discussion}

Growth rate differences between blue grama and green needlegrass would probably have been more pronounced at higher light intensities than those used in this study. The light intensity in the temperature treatment phase of the experiment was less than $25 \%$ of full sunlight. Green needlegrass was probably near light saturation, while blue grama was much below its light saturation level. Photosynthesis of most $\mathrm{C}_{3}$ species is saturated at intensities of $25 \%$

Table 4. Simple correlation coefficients $(\tau)$ and linear regression coefficients (b) for the relationship between relative growth rate $\left(K_{w}\right)$ and net assimilation rate (NAR), leaf area partitioning coefficient (LAP), and relative leaf area expansion rate $\left(K_{a}\right)$ of 2 accessions each of green needlegrass and blue grama.

\begin{tabular}{lllll}
\hline \hline \multirow{2}{*}{$\begin{array}{l}\text { Bivariate relationship } \\
\text { and coefficient }\end{array}$} & \multicolumn{4}{c}{ Accession } \\
\cline { 2 - 5 } Kodorm & SD-93 & PM-K-1482 & PM-K-1483 \\
\hline KAR & $0.69^{* 2}$ & $0.78^{* *}$ & $0.85^{* *}$ & $0.75^{*}$ \\
b & 0.02 & 0.03 & 0.04 & 0.04 \\
K $_{w^{-}}$LAP & & & & \\
b & -0.43 & -0.52 & -0.11 & 0.38 \\
$\mathrm{~K}_{\mathrm{w}}-\mathrm{K}_{\mathrm{a}}$ & -0.46 & -0.68 & -0.56 & 1.54 \\
$\mathrm{~b}$ & & & & \\
\hline
\end{tabular}

\footnotetext{
*** Significant at the 0.05 and 0.01 levels, respectively

The dependent variable is listed first for each growth characteristic relationship. - Data represents the combined analysis of data from the $20-15^{\circ} \mathrm{C}$ and $25-20^{\circ} \mathrm{C}$ temperature treatments.
}

of full sunlight, while photosynthesis of $\mathrm{C}_{4}$ species is generally not saturated at $100 \%$ of full sunlight (Moore 1977).

Potter and Jones (1977) reported that $\mathbf{K}_{\mathbf{w}}$ was highly correlated with LAP for 7 of the 9 species they studied and that a low correlation between $K_{w}$ and NAR existed for 5 species. NAR was a more important factor than LAP in growth of green needlegrass and blue grama seedlings under the conditions of our study. Potter and Jones (1977) found that temperature differences affected $K_{w}$ and LAP but for 4 of the species they studied had little effect on NAR. Our results were interpreted to show that NAR was affected by temperature differences, especially for blue grama.

Results of this study were in agreement with results of other studies (Potter and Jones, 1977. Patterson et al. 1978, lownsend and Wilson 1981) in which high correlations between seedling growth and $K_{a}$ were found. $K_{a}$ appeared to be the major growth trait related to differences in growth rates between Lodorm green needlegrass and blue grama seedlings. The importance of $\mathbf{K}_{\mathbf{a}}$ in seedling growth is supported by Townsend and Wilson (1981) who found that although NAR was significantly correlated with growth of cicer milkvetch seedlings, it tended to affect growth indirectly through its effect on $K_{a}$.

The highest NAR for green needlegrass and blue grama seedlings recorded under the conditions of this study was 2.2 and $3.8 \mathrm{mg}$ dry matter $\mathrm{cm}^{-2} \mathrm{day}^{-1}$, respectively. The higher NAR of blue grama reflects the greater photosynthetic capacity of plants that photosynthesize by the $\mathrm{C}_{4}$ pathway. Field studies by Wilson and Briske (1979) yielded lower NAR measurements than those recorded for plants grown in growth chambers in the present study. They reported rates of 2.6 to $3.0 \mathrm{mg}$ biomass $\mathrm{cm}^{-2}$ day ${ }^{-1}$ during the early summer for blue grama seedlings harvested from seeded stands at the Central Plains Experimental Range in northeastern Colorado.

Grcen needlegrass has been used extensively in the northern Great Plains in range seeding mixtures and in mined-land reclamation plantings (Thornburg 1982). Differences in relative growth rate and relative rate of root development per shoot between green needlegrass accessions indicate the possibility of selecting green needlegrass for rapid seedling growt h and rapid root development. Slow growth during the seedling stage is one of the primary reasons for difficulty in grass establishment in semiarid regions (Vallentine 1980). Development of varieties with rapid seedling growth and root development in addition to low seed dormancy would enhance the value of green needlegrass for use in reseeding of deteriorated rangeland and in revegetation of strip mined and other drastically disturbed lands.

\section{Literature Cited}

Larson, K.L., and J.F. Carter. 1970. Lodorm green needlegrass- $\cdots$ A new variety for revegetating rangeland. N. Dak. Farm Res. 27:6-8.

Moore, R.T. 1977. Gas exchange and photosynthetic pathways in rangc plants, p. 1-46. In: R.E. Sosebee (ed.), Rangeland Plant Physiology. Range Science Series 5. Society for Range Manage., Denver. Colo.

Patterson, D.T., C.R. Meyer, and P.C. Quimbly, Jr. 1978. Effects of irradiance on relative growth rates, net assimilation rates. and leaf area partitioning in cotton and three associated weeds. Plant Physiol. 62:14-17.

Potter, J.R., and J.W. Jones. 1977. Leaf a rea partitioning as an important factor in growth. Plant Physiol. 59:10-14.

Thornburg, A.A. 1982. Plant materials for use on surface mined lands in arid and semi-arid regions. USDA-SCS. SCS-TP-157.

Townsend, C.E., and A.M. Wilson. 1978. Seedling growth of cicer milkvetch in controlled environments. Crop Sci. 18:662-666.

Townsend, C.E., and A.M. Wilson. 1981. Seedling growth of cicer milkvetch as affected by seed weight and temperature regime. Crop Sci. 21:405-409.

Vallentine, J.F. 1980. Range development and improvements. Brigham Young University Press, Provo. Utah.

Waller, S.S., and J.K. Lewis. 1979. Occurrence of $C_{3}$ and $C_{4}$ photosynthetic pathways in North American grasses. J. Range Manage. 32:12-28.

Wilson, A.M., and D.D. Briske. 1979. Scminal and adventitious root growth of blue grama seedlings on the central plains. J. Range Manage. 32:209-213. 